\title{
Right ventricular thrombus after penetrating cardiac injury
}

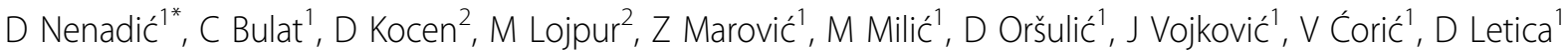 \\ From 23rd World Congress of the World Society of Cardio-Thoracic Surgeons \\ Split, Croatia. 12-15 September 2013
}

\section{Background}

To report a case of thrombus formation ten days after penetrating cardiac injury to the right ventricle.

\section{Methods}

A 37 year old man had been stabbed with a knife to the epigastric area. Twenty minutes after the incident he was admitted to the University Hospital Centre Split. After aggressive resuscitation the patient was transferred to emergency operating theatre without any prior diagnostic procedures. Abdominal cavity was explored by laparotomy, and no evident damage to the abdominal organs was found. Because of hemodynamic instability and high suspicion of cardiac tamponade a left thoracotomy was performed and the stab wound measuring $40 \mathrm{~mm}$ in length to the right ventricle was located $20 \mathrm{~mm}$ away from middle third of the left anterior descending artery. Because of space restrictions it was decided to do a middle sternotomy. The entry wound was explored and sutured with two pledgeted 4.0 polypropylene sutures, without the support of the heart-lung machine.

\section{Results}

Patient spent two days in intensive care unit. After ten days of hospital stay the patient was discharged with normal echocardiography findings. After three weeks a control transthoracic echocardiography was performed and a right ventricle thrombotic mass measuring $27 \mathrm{~mm} \mathrm{x}$ $19 \mathrm{~mm} \times 13 \mathrm{~mm}$ was detected. Immediately after that find the patient was treated with enoxaparine (low molecular weight heparin) for ten days.

At control magnetic resonance imaging (MRI) no thrombotic mass was found in the right ventricle.

\footnotetext{
* Correspondence: denisnenadic@yahoo.com

'Department of Cardiac Surgery, School of Medicine, University Hospital Centre Split, Croatia
}

Full list of author information is available at the end of the article

\section{Conclusion}

Out of this case it is evident that patients with penetrating cardiac injuries should to be intensively monitored by echocardiography during the first few weeks after injury, due to high risk of thrombotic mass formation at the repaired wall of the myocardium.

\section{Authors' details}

'Department of Cardiac Surgery, School of Medicine, University Hospital Centre Split, Croatia. ${ }^{2}$ Department of Anesthesiology, School of Medicine, University Hospital Centre Split, Split, Croatia.

Published: 11 September 2013

\section{doi:10.1186/1749-8090-8-S1-P33}

Cite this article as: Nenadić et al:: Right ventricular thrombus after penetrating cardiac injury. Journal of Cardiothoracic Surgery 2013 8(Suppl 1):P33.
Submit your next manuscript to BioMed Central and take full advantage of:

- Convenient online submission

- Thorough peer review

- No space constraints or color figure charges

- Immediate publication on acceptance

- Inclusion in PubMed, CAS, Scopus and Google Scholar

- Research which is freely available for redistribution

Submit your manuscript at www.biomedcentral.com/submit
C Bïomed Central

\section{Biomed Central}

